\title{
Structural reliability assessment of existing precast concrete building. Case study
}

\author{
Pēteris Druķis ${ }^{1}$, Līga Gaile ${ }^{2}$, Vadims Goremikins ${ }^{3}$ \\ Insitute of Structural Engineering and Reconstruction, Riga Technical University, Kalku Street 1, Riga, Latvia \\ E-mail: ${ }^{1}$ peteris.drukis@gmail.com (corresponding author)
}

\begin{abstract}
Structural reliability of buildings has become an important issue during the last decades. Reliability of building is the practice of designing, constructing, operating, maintaining and removing buildings in such a way, which prevents the health deterioration, injuries or death during the use of the building. Evaluation and improvement of existing buildings becomes more and more substantial.

For the most of the existing buildings the design life has been already reached or will be reached in the nearest future. The structures of these buildings need to be reassessed in order to find out whether the safety requirements are met. The safety requirements provided by the Eurocodes are starting point for the assessment of reliability. However, it would be uneconomical to require all existing buildings and structures to fully comply with these new codes and corresponding reliability levels.

Therefore, the assessment of existing buildings differs from design situation. This case study describes the practice of determination of reliability level of structures of existing public building designed in accordance with different codes/regulations that differ from Eurocodes. It allows to reassess the actual reliability level of existing buildings under the operational load. Also, the evaluation methodology of the global reliability level of the whole building in terms of mechanical strength and stability of building is proposed.
\end{abstract}

Keywords: Reliability of structures, reliability assesment, global reliability, safety of existing buildings.

\section{Introduction}

According to Eurostat (Commission staff working document impact assessment, 2016), currently $>35 \%$ of buildings in Europe are over 50 years old. According to the design norms of these buildings the lifetime of these buildings has passed and nowadays there are different views on whether using of those buildings should be ended as they pose a threat to society and the environment, or the further use of these buildings is acceptable.

Besides/Additionally there are data (OpenExp, 2016) for the time period from 1980 to 2007 about construction work related to new and existing structures, showing a steady increase in the proportion of existing constructions. In the engineering environment, there are often discussions on the following 3 issues:

What is the reliability level of existing buildings?

In general, existing buildings, if properly operated, are considered safe for humans and the environment. However, due to the technological advances, as well as regulatory requirements related to the growth and aging of society, the tasks of both owners and service personnel, using this building, are becoming more complicated.

Existing buildings has been designed to meet the safety level of the time when they were built, while today's level of safety is higher. There are also new requirements for the safety level of the building, the provision of which requires additional resources from the building owners, so the special attention is paid to the safety of building structures in today's conditions. This especially applies for the socially important buildings or public buildings in accordance with regulatory requirements (Construction Law, 2013).

Different buildings, depending on the age of their construction, have different safety levels. In view of the fact that users of a building are basically counting on the same level of safety, there may be situations which cause accidents only because the building does not provide the level of safety that its user expects.

Although most of Latvia's buildings have been built more than 20 years ago, when the Soviet construction standards were in force, there are also buildings which were constructed by 2010 in accordance with national construction standards, as well as buildings in recent years, when the construction standards and standards of the European Union are is valid in Latvia, including Eurocodes. 
Similarly, despite the regulatory framework that the owner of the building must maintain his or her building in a safe state, in practice owners are not always able to provide it. And it also has its own objective reasons.

The European Union, by special regulation (EU Regulation for construction products, 2011) on harmonised conditions for the marketing of construction products, with Annex 1 "Basic requirements", has set out seven requirements that are binding on all buildings built and used in the European Union, regardless of their construction time, owner, location or type.

Such requirements did not apply when these buildings were constructed, but this does not relieve the building owner of the obligation to ensure that their building complies with these requirements. This is especially the case for buildings occupied by the public or Public buildings (LBN 208-15, 2015). It requires considerable resources and expertise, but building owners are not always able to ensure it.

What to do with buildings for which the design lifetime of the structures is over?

This is an issue that has become topical in society in recent decades. Should such buildings be demolished? Should their structures be changed? If not, who will take responsibility for their safety during their future lifetime? What should be the level of safety for a building after its refurbishment (renovation) or reconstruction? What period should the building's lifetime be extended and who is responsible for it?

The existing regulatory framework for constructions concerns the design and construction of new structures and does not include requirements for the assessment and safety of existing structures. Structural standards are based on the assumption that they will serve for a certain period of time, but they do not specify requirements for handling structures after this period expires.

Should the structures that have expired for which they were designed be considered unsafe and should be discontinued? If not, then what is their future term of use? This issue is particularly relevant in the case of partial refurbishment or renovation of the building and the mixing of new structures with existing structures. Does the designer/builder of the new structures also take responsibility for the old structures? Would the estimated life of the new structures be extended to existing structures?

\section{How to evaluate the reliability level of existing structures?}

There are significant differences between design and assessment. Design uncertainties arise from the designed load and resistance characteristics of the new structures. These uncertainties are representative of dispersal due to the characteristics of the various structures due to the inconsistency of the quality of the materials used in them, the different construction technologies and the distribution of the specific loads at the site. A conservative design will not lead to a significant increase in the cost of structures, whereas a conservative assessment can lead to unnecessary and costly repairs or reconstructions, or end up in the other extreme - not to discover significant problems in the use of a building can lead to tragic consequences.

These issues are topical for today's civil engineering and construction professionals, including building science. In 2015, the European Commission's Research Centre (Joint Research Centre) presented a special science and policy report on activities in regulatory frameworks and research related to the assessment of reliability of existing structures (Luechinger \& Fischer, 2015), highlighting challenges for existing structures.

The authors of this publication are working on research to answer the above questions. This publication describes a practical example of assessing the global reliability of an existing building and to provide the answers for the above mentioned questions.

\section{Materials and methods}

\section{General}

Overall, the condition of the existing buildings is not improving. There are a numbers of publication about optimisation of structures in terms of reliability, but question is - is it acceptable for structures in use? According to studies, damage has been detected in a large part of the building's carrying structures (Drukis, Gaile, \& Pakrastins, 2017c), so what is the matter of the reliability of these buildings?

ISO 13822, as well as a numbers of different publications define the main principles for the activities to be carried out in the detailed assessment of the structures. Publications that provide practical examples of detailed assessment studies with a view to evaluate the reliability of buildings are not numerous and are basically about the reliability of individual structures rather than the overall safety of the building (Diamantidis \& Bazzurro, 2010; Nico, Scholten, \& Vrouwenvelder, 2013; Holicky, Diamantidis, \& Sykora, 2015; FIB 80, 2016).

There were the researches done to establish the reliability levels for existing building structures by authors (Drukis, Gaile, \& Goremikins, 2017b; Drukis, Gaile, Valtere, Pakrastins, \& Goremikins, 2017a). The developed simple and practical procedure of determination of minimal reliability index $\beta$ of existing structure designed by different codes than Eurocodes allows to assess the actual safety level of different structural elements of buildings. Now, after the number of evaluation of existing buildings the new method is presented for global assessment of reliability level of 
building structures. This method allows to establish the overall (global) reliability of the building and to judge about mechanical strength and stability of whole building.

\section{Global reliability of the building}

The global reliability of the building, or its mechanical strength and stability, is characterized by the reliability of certain structural elements. In order to determine the probability of collapse of the whole building, it is suggested to act in accordance with the safety principle established by Eurocodes, namely the partial factors of the boundary states of resistance for the various materials and load effects are verified in such a way that the level of reliability for a representative structure is as close as possible to the target reliability index $\beta$ (Implementation of Eurocodes. Handbook 2, 2005).

In order to determine the global reliability index of a building, it is important to analyse and establish the existing structural scheme of the building accurately and to determine the load effects for individual elements. Depending on the consequences of the collapse of these loaded elements, the reliability index of the whole building may change (Perel'muter, \& Pichugin, 2014). Therefore, in addition to the existing structure reliability index $\beta$, the weighting factor as variable is introduced. The weighting factor $\mathrm{W}$ describe the 3 characters of every bearing element in the structural scheme (see Table 1).

Table 1. Distribution of bearing structures by their weighting

\begin{tabular}{|c|c|c|}
\hline $\begin{array}{l}\text { Symbol and name of influence of } \\
\text { separate bearing structure }\end{array}$ & Weighting description & $\begin{array}{l}\text { Value of weighting } \\
\text { factor }\end{array}$ \\
\hline \multicolumn{3}{|c|}{ Weighting by load character, $w_{l}$} \\
\hline GS (global stability) & $\begin{array}{l}\text { The element ensures overall stability of the building, partici- } \\
\text { pates in the transfer of horizontal loads }\end{array}$ & 0.1 \\
\hline LS (local stability) & $\begin{array}{l}\text { The element ensures stability of other elements (in case, if the } \\
\text { item has no other function, e.g. bracing) }\end{array}$ & 0.1 \\
\hline HL (horizontal loads) & The element receives horizontal loads & 0.1 \\
\hline VL (vertical loads) & The element receives vertical loads & 0.2 \\
\hline VHL (vertical horizontal loads) & The element receives horizontal and vertical loads & 0.3 \\
\hline \multicolumn{3}{|c|}{ Weighting by failure character, $w_{f}$} \\
\hline SF (single failure) & $\begin{array}{l}\text { The element directly absorbs the load (the collapse of purlins, } \\
\text { the collapse of prefabricated slab) }\end{array}$ & $0.01-0.1$ \\
\hline LF (local failure) & $\begin{array}{l}\text { The element supporting other elements, the collapse of span or } \\
\text { double span in one level (e.g. beam collapse, truss collapse to- } \\
\text { gether with purlins, secondary beams, the collapse of column } \\
\text { in upper floor) }\end{array}$ & $0.2-0.5$ \\
\hline GF (global failure) & $\begin{array}{l}\text { The collapse of building or part of it (the collapse of the col- } \\
\text { umn, which also causes the collapse of other structures) }\end{array}$ & $0.5-1.0$ \\
\hline \multicolumn{3}{|c|}{ Weighting by consequence character, $w_{c}$} \\
\hline LC (low consequence) & The collapse of light structures with small span & $0.01-0.1$ \\
\hline MR (medium consequence) & $\begin{array}{l}\text { The collapse of light structures with big span/ the collapse of } \\
\text { heavy structures with small span }\end{array}$ & $0.2-0.3$ \\
\hline HR (high consequence) & The collapse of heavy structure with big span & $0.4-0.6$ \\
\hline
\end{tabular}

The total weighting factor $\mathrm{W}$ is calculated:

$$
\mathrm{W}=w_{l}+w_{f}+w_{c},
$$

where: $w_{l}$ - weighting factor by load character, $w_{f}$ - weighting factor by failure character, $w_{c}-$ weighting factor by consequence character.

There are examples of structural elements and the principle for calculation of their weighting factor W (see Table 2).

Considering that the probability of collapse of certain structures and consequences of such collapse directly correlate with probability of collapse of the whole building and consequences of such collapse, we can use the equation how to find the weighted geometric mean of a data set, when the product of values is significant (Puyenbroeck $\&$ Rogge, 2016).

$$
\Lambda_{G R I}=\left(\prod_{i=1}^{n} \beta_{i}^{W_{i}}\right)^{1 / \sum_{i=1}^{n} W_{i}},
$$

where: $\mathrm{W}_{\mathrm{i}}$ - structural element weighting factor in case of its collapse; $\beta_{\mathrm{i}}$ - reliability index of structural element. 
Table 2. The examples of weighting factor w calculation

\begin{tabular}{|c|c|c|c|}
\hline Structural element & Description & $\begin{array}{c}\text { Combination of } \\
\text { influances }\end{array}$ & $\begin{array}{l}\text { Total weighting } \\
\text { factor, W }\end{array}$ \\
\hline $\begin{array}{l}\text { Top-floor central column } \\
\text { with pinned ends }\end{array}$ & $\begin{array}{l}\text { Column takes only vertical load / collapse of col- } \\
\text { umn resulting in collapse of two span structure / } \\
\text { collapse of structures supported by column can } \\
\text { damage lower structures and people }\end{array}$ & $\mathrm{VL}+\mathrm{LC}+\mathrm{HC}$ & $0.2+0.2+0.4=0.8$ \\
\hline $\begin{array}{l}\text { Big span truss supporting } \\
\text { reinforced concrete slabs }\end{array}$ & $\begin{array}{l}\text { Take loads in a vertical direction, take part to } \\
\text { transfer the horizontal loads/the collapse of truss } \\
\text { cause the collapse of span structures/collapse of } \\
\text { concreate slabs can damage lower structures and } \\
\text { people }\end{array}$ & $\mathrm{VL} / \mathrm{GS}+\mathrm{LC}+\mathrm{HC}$ & $0.3+0.2+0.4=0.9$ \\
\hline $\begin{array}{l}\text { Metal beam supporting re- } \\
\text { inforced concrete slabs }\end{array}$ & $\begin{array}{l}\text { Take loads in a vertical direction, take part to } \\
\text { transfer the horizontal loads/the collapse of beam } \\
\text { cause the collapse of span structures/collapse of } \\
\text { concreate slabs can damage lower structures and } \\
\text { people }\end{array}$ & $\mathrm{VL} / \mathrm{GS}+\mathrm{LC}+\mathrm{MC}$ & $0.3+0.2+0.2=0.7$ \\
\hline Purlin & $\begin{array}{l}\text { Take loads in a vertical direction/the collapse of } \\
\text { element cause the partly collapse of covers/option } \\
\text { to injure a people is low }\end{array}$ & $\mathrm{VL}+\mathrm{SC}+\mathrm{LC}$ & $0.2+0+0=0.2$ \\
\hline Prefabricated slab & $\begin{array}{l}\text { Take loads in a vertical direction/the collapse of } \\
\text { element not cause the collapse other elements/dur- } \\
\text { ing of the collapse other elements can be dam- } \\
\text { aged, people injured }\end{array}$ & $\mathrm{VL}+\mathrm{SC}+\mathrm{MC}$ & $0.2+0+0.2=0.4$ \\
\hline $\begin{array}{l}\text { First floor inner wall sup- } \\
\text { porting reinforced concrete } \\
\text { slabs }\end{array}$ & $\begin{array}{l}\text { Take loads in a vertical direction, take part to } \\
\text { transfer the horizontal loads and insure of stability } \\
\text { of building / collapse of element resulting in col- } \\
\text { lapse of two span structure /during of the collapse } \\
\text { other elements can be damaged, people injured }\end{array}$ & $\mathrm{VL} / \mathrm{GS}+\mathrm{GC}+\mathrm{HC}$ & $0.3+0.4+0.4=1.1$ \\
\hline $\begin{array}{l}\text { Carrying outer wall in one- } \\
\text { storey building }\end{array}$ & $\begin{array}{l}\text { Take loads in a vertical and horizontal direction, } \\
\text { take part to transfer the horizontal loads and in- } \\
\text { sure of stability of building / collapse of element } \\
\text { resulting in collapse of one span structure /during } \\
\text { of the collapse other elements can be damaged, } \\
\text { people injured }\end{array}$ & $\mathrm{VHL} / \mathrm{GS}+\mathrm{LC}+\mathrm{MC}$ & $0.4+0.2+0.2=0.8$ \\
\hline $\begin{array}{l}\text { Vertical purlin in steel } \\
\text { frame building }\end{array}$ & $\begin{array}{l}\text { Take part to transfer the horizontal loads and in- } \\
\text { sure of stability of building / collapse of element } \\
\text { resulting in collapse of whole building }\end{array}$ & $\mathrm{GS}+\mathrm{GC}+\mathrm{HC}$ & $0.1+0.4+0.4=0.9$ \\
\hline
\end{tabular}

Equation (2) characterise the total mechanical strength and stability of a building and here and after named as global reliability index of building $\Lambda_{\mathrm{GRI}}$.

There is relation between the probability of the collapse of the structure $P_{f}$ and the reliability index $\beta$ (Implementation of Eurocodes. Handbook 2, 2005):

$$
P_{f}=\Phi(-\beta),
$$

where $\Phi$ is the cumulative distribution function of the standardised Normal distribution. The relation between $P_{f}$ and $\beta$ is given in Figure 1 .

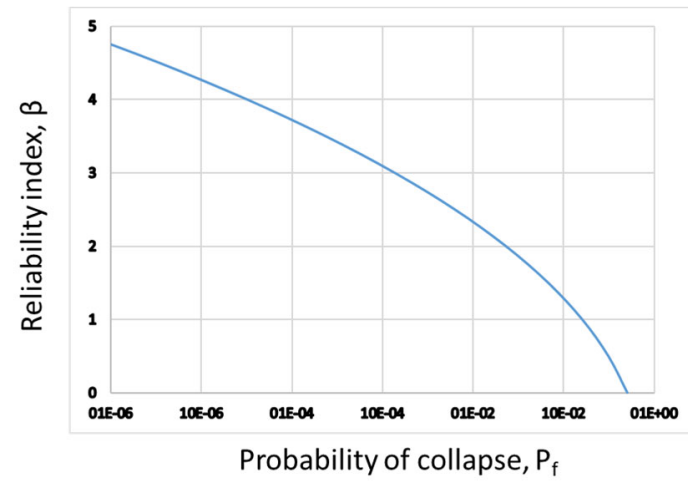

Figure 1. Relation between $P_{f}$ and $\beta$ 
The probability of the building total collapse $P_{f}$ is suggested to be analogous to the probability of the individual element collapsing, with the cumulative distribution function of the standardised Normal distribution:

$$
P_{f}=\Phi\left(-\Lambda_{G R I}\right)
$$

where $\Lambda_{\mathrm{GRI}}$ is global reability index of building.

\section{Determination of global reliability of building}

The newly developed procedure of determination of global reliability of building $\Lambda_{\mathrm{GRI}}$ for existing buildings is presented via case study. For the case study a structures of existing building in Valmiera, Latvia is chosen. The building was built in 1986 , total square meter is $18.446 \mathrm{~m}^{2}$, consequence class according to EN 1990 - CC2, one underground floor and 3 above ground floors, structures mainly from prefabricated concrete elements. The configuration of the building is presented in the Figure 2.

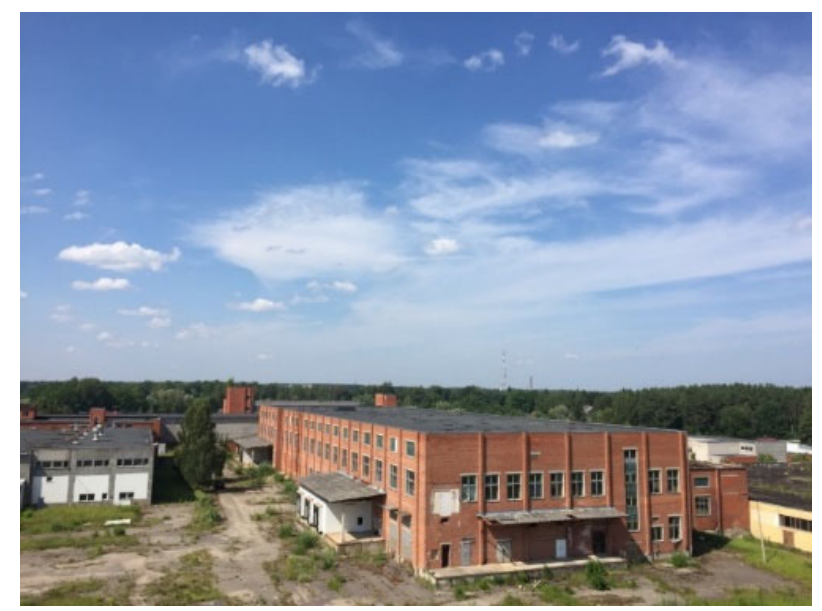

Figure 2. The existing building in Valmiera

After a detailed study of the building's documentation and inspection of the main building's structures, it was decided that one of the sections of the building would serve as a rating for the overall mechanical strength and stability of the building, as its elements and structural scheme actually characterize the rest of the building. The structural scheme for the existing section was detected (see Figure 3).

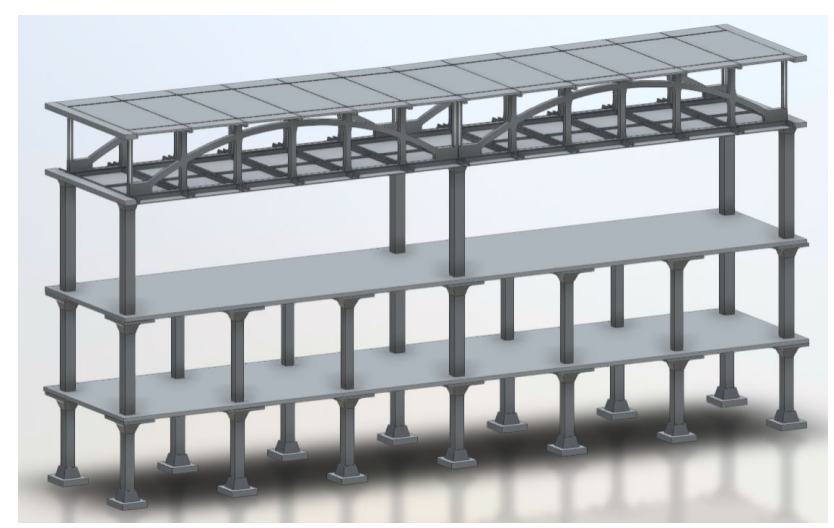

Figure 3. The structural scheme for the existing section

The section describing the mechanical strength and stability of the building consists of the following elements (see Table 3).

During the inspection of structural elements, no signs (e.g. deflections or cracks) of overloading of the structures were found, and it is assumed that the load-bearing capacity of the element is $10 \%$ higher than the design effects. Used partial factor for a material property, also accounting model uncertainties and dimensional variations $\gamma_{\mathrm{M}} 1.2$; coefficient of variation for concrete structures $\mathrm{V}_{\mathrm{R}}=0.15$, coefficient of variation of imposed and snow load $\mathrm{V}_{\mathrm{Q}}=0.6$, coefficient of variation of self-weight $V_{G}=0.1$ (Implementation of Eurocodes. Handbook 2, 2005). 
Table 3. Number of elements in the section and their characterisations

\begin{tabular}{|l|c|c|c|}
\hline \multicolumn{1}{|c|}{ Structural element } & Number of elements & Combination of weightings & Weighting factor, W \\
\hline Basement level slabs & 6 & $\mathrm{VL}+\mathrm{SC}+\mathrm{MC}$ & $0.2+0.1+0.2=0.5$ \\
\hline Basement side columns & 4 & $\mathrm{VHL} / \mathrm{GS}+\mathrm{GC}+\mathrm{HC}$ & $0.4+0.5+0.5=1.4$ \\
\hline Basement middle columns & 8 & $\mathrm{VL} / \mathrm{GS}+\mathrm{LC}+\mathrm{MC}$ & $0.3+0.3+0.3=0.9$ \\
\hline Basement central columns & 2 & $\mathrm{VHL} / \mathrm{GS}+\mathrm{GC}+\mathrm{HC}$ & $0.4+0.9+0.6=1.9$ \\
\hline 1st floor level slabs & 6 & $\mathrm{VL}+\mathrm{SC}+\mathrm{MC}$ & $0.2+0.1+0.2=0.5$ \\
\hline 1st floor side columns & 4 & $\mathrm{VHL} / \mathrm{GS}+\mathrm{GC}+\mathrm{HC}$ & $0.4+0.5+0.5=1.4$ \\
\hline 1st floor middle columns & 8 & $\mathrm{VL} / \mathrm{GS}+\mathrm{LC}+\mathrm{MC}$ & $0.3+0.3+0.2=0.8$ \\
\hline 1st floor central columns & 2 & $\mathrm{VHL} / \mathrm{GS}+\mathrm{GC}+\mathrm{HC}$ & $0.4+0.7+0.6=1.7$ \\
\hline 2nd floor level slabs & 24 & $\mathrm{VL}+\mathrm{SC}+\mathrm{MC}$ & $0.2+0+0.2=0.4$ \\
\hline 2nd floor side columns & 4 & $\mathrm{VHL} / \mathrm{GS}+\mathrm{GC}+\mathrm{HC}$ & $0.4+0.5+0.4=1.3$ \\
\hline 2nd floor central columns & 2 & $\mathrm{VHL} / \mathrm{GS}+\mathrm{GC}+\mathrm{HC}$ & $0.4+0.7+0.6=1.7$ \\
\hline Roof level slabs & 24 & $\mathrm{VL}+\mathrm{SC}+\mathrm{MC}$ & $0.2+0+0.2=0.4$ \\
\hline Roof level truss & 4 & $\mathrm{VHL} / \mathrm{GS}+\mathrm{GC}+\mathrm{HC}$ & $0.4+0.5+0.4=1.3$ \\
\hline
\end{tabular}

After a detailed study of the construction documentation of the building and research of the main constructions, the following results for the reliability analysis were obtained (see Table 4).

Table 4. Characteristics of effects and resistance for structural elements

\begin{tabular}{|l|c|c|c|c|c|c|c|c|}
\hline \multirow{2}{*}{ Structural element } & $\mathbf{E}_{\mathbf{G k}}$ & $\mathbf{E}_{\mathbf{G d}}$ & $\mathbf{E}_{\mathbf{Q k}}$ & $\mathbf{E}_{\mathbf{Q d}}$ & $\mathbf{E}_{\mathbf{d}}$ & $\mathbf{R}_{\mathbf{d}}$ & $\mathbf{R}_{\mathbf{k}}$ & $\boldsymbol{\Delta}$ \\
\cline { 2 - 10 } & $\mathrm{kN} / \mathrm{m}^{2}$ & $\mathrm{kN} / \mathrm{m}^{2}$ & $\mathrm{kN} / \mathrm{m}^{2}$ & $\mathrm{kN} / \mathrm{m}^{2}$ & $\mathrm{kN} / \mathrm{m}^{2}$ & $\mathrm{kN} / \mathrm{m}^{2}$ & $\mathrm{kN} / \mathrm{m}^{2}$ & $\%$ \\
\hline Basement level slabs & 6.64 & 7.94 & 10 & 12 & 19.94 & 22.15 & 26.58 & 40 \\
\hline Basement columns & 1044.7 & & 642 & & 2216 & 2462 & 2954 & 30 \\
\hline 1st floor level slabs & 6.64 & 7.94 & 10 & 12 & 19.94 & 22.15 & 26.58 & 20 \\
\hline 2nd floor level slabs & 1.99 & 2.29 & 0.7 & 0.91 & 3.2 & 3.2 & 3.84 & 40 \\
\hline 1st; 2nd floor columns & 350 & & 110 & & 552 & 613 & 736 & 15 \\
\hline Roof level slabs & 3.49 & 4.24 & 1.25 & 1.75 & 5.99 & 6.66 & 8 & 25 \\
\hline Roof level truss & 4.99 & & 1.25 & & 7.74 & 14.1 & 16.8 & 10 \\
\hline
\end{tabular}

where $\mathbf{E}_{\mathbf{G k}}-$ Characteristic value of effect of permanent actions; $\mathbf{E}_{\mathbf{G d}}-$ Design value of effect of permanent actions; $\mathbf{E}_{\mathbf{Q k}}-$ Characteristic value of effect of variable actions; $\mathbf{E}_{\mathbf{Q d}}-$ Design value of effect of variable actions; $\mathbf{E}_{\mathbf{d}}-$ Design value of effect of actions; $\mathbf{R}_{\mathbf{d}}-$ Design value of the resistance; $\mathbf{R}_{\mathbf{k}}-$ Characteristic value of the resistance; $\Delta, \mathbf{\%}-$ deterioration of structural elements, which reduce characteristic value of the resistance, in percentage.

In a further study the reliability index of each individual structural element was obtained according to the methods described in previous publications (Drukis et al., 2017b, 2017a), and the index and probability of collapse of the total mechanical strength and stability of the building were determined according to the above. The results are presented in the next chapter.

\section{Results}

After relevant calculations the following reliability indexes $\beta$ and probabilities of collapse of the structural elements $P_{f}$ in the building were obtained (see Table 5).

Table 5. Reliability indexes $\beta$ and probabilities of collapse of the structural elements $P_{f}$ in the building

\begin{tabular}{|l|c|c|c|c|}
\hline \multicolumn{1}{|c|}{ Structural element } & Number of elements & $\begin{array}{c}\text { Influence factor, } \\
\text { W }\end{array}$ & $\begin{array}{c}\text { Reliability index, } \\
\beta\end{array}$ & $\begin{array}{c}\text { Probability of collapse, } \\
P_{f}\end{array}$ \\
\hline Basement level slabs & 6 & 0.5 & 2.8 & $2.6 \mathrm{E}-03$ \\
\hline Basement side columns & 4 & 1.4 & 2.8 & $2.6 \mathrm{E}-03$ \\
\hline Basement middle columns & 8 & 0.9 & 2.8 & $2.6 \mathrm{E}-03$ \\
\hline Basement central columns & 2 & 1.9 & 2.8 & $2.6 \mathrm{E}-03$ \\
\hline
\end{tabular}




\begin{tabular}{|l|c|c|c|c|}
\hline Structural element & Number of elements & $\begin{array}{c}\text { Influence factor, } \\
\mathrm{W}\end{array}$ & $\begin{array}{c}\text { Reliability index, } \\
\beta\end{array}$ & $\begin{array}{c}\text { Probability of collapse, } \\
P_{f}\end{array}$ \\
\hline 1st floor level slabs & 6 & 0.5 & 3.6 & $1.6 \mathrm{E}-04$ \\
\hline 1st floor side columns & 4 & 1.4 & 3.2 & $6.9 \mathrm{E}-04$ \\
\hline 1st floor middle columns & 8 & 0.8 & 3.2 & $6.9 \mathrm{E}-04$ \\
\hline 1st floor central columns & 2 & 1.7 & 3.2 & $6.9 \mathrm{E}-04$ \\
\hline 2nd floor level slabs & 12 & 0.4 & 1.2 & $1.2 \mathrm{E}-01$ \\
\hline 2nd floor side columns & 4 & 1.3 & 3.2 & $6.9 \mathrm{E}-04$ \\
\hline 2nd floor central columns & 2 & 1.7 & 3.2 & $6.9 \mathrm{E}-04$ \\
\hline Roof level slabs & 12 & 0.4 & 2.8 & $2.6 \mathrm{E}-03$ \\
\hline Roof level truss & 4 & 1.3 & 5.5 & $1.9 \mathrm{E}-08$ \\
\hline
\end{tabular}

After calculations according to formula (2), the global reliability index of the building is obtained:

$$
\Lambda_{\mathrm{GRI}}=2.959 \text {. }
$$

Using formula (4) the building's probability of collapse is (when 50 years of reference period is considered)

$$
P_{f}=\Phi(-2.959)=1.6^{*} 10^{-3} \text {. }
$$

\section{Conclusions}

The developed simple and practical procedure of determination of global reliability of building allows to assess the actual reliability level of buildings during of their operation. It is very important to Latvia, as most of the existing buildings are designed in accordance with different structural codes and actual reliability level generally is unknown. Therefore, often arises the question whether these buildings need to be strengthened to reach the safety level of the current design codes

Two performance indicators, the reliability index and the weighting factor of main structures in the building have been considered to define the global reliability of building. Different weighting models of the same element have been analysed, as well as different correlation among structural failure modes. The approach presented has broad applicability to any building that can be adequately modelled as a system of structural elements, where reliability index of those elements can be assessed and weighted. The conclusions are as follows:

For new building structures the target reliability index with reference period 50 years is 3.8 (CC2) Implementation of Eurocodes. Handbook 2, 2005). For existing buildings, the target reliability index due to economic and social aspects can be reduce to 2.3 (for CC2) (Sykora, Holicky, Jung, \& Diamantidis, 2015). The result of this case study shows the target reliability index 2.96 for whole building and it can be acceptable according to previous studies.

The low reliability level of separate structural element doesn't play important influence to global reliability index if there is a low weighting factor. For example, 2nd floor level slabs have reliability index 1.2, but due to weighting factor 0.4 its influence to the global reliability of building is insignificant.

Although the results of the case study show that the proposed method for determination of global reliability of building is working, a series of studies are still necessary for the calibration of the proposed weighting factors of structural elements. Their Inaccurate choice or improper use of them has a significant impact on the building reliability level.

\section{Discussions}

The case study of the existing building revealed that the global reliability index $\Lambda$ depends on reliability level of separate structural elements, their weighting factors and numbers of those elements.

Certainly, further research is necessary for the decision making, based on combining of several weighting indicators of the structural elements.

Also the level of probability of collapse should be evaluated in further studies, because, in accordance with the several studies (Perel'muter \& Pichugin, 2014), the risk, which is higher than $10^{-5}$, is not acceptable. Therefore, the correlation between probability of collapse in the target reference period and unacceptable risk should be evaluated in the further studies. 


\section{References}

Cabinet of Ministers of Latvia. (2015). LV Regulation for Public Buildings (LBN 208-15). Riga, 30.06.2015. Retrieved from https://likumi.lv/ta/id/274995-noteikumi-par-latvijas-buvnormativu-lbn-208-15-publiskas-buves-

Commission staff working document impact assessment. (2016). Proposal for a directive of the European Parliament and of the Council amending Directive 2010/31/EU on the energy performance of buildings. European Commission. Retrieved from https://ec.europa.eu/energy/sites/ener/files/documents/1_en_impact_assessment_part1_v3.pdf

Diamantidis, D., \& Bazzurro, P. (2010). Safety acceptance criteria for existing structures. University of Applied Sciences, Regensburg.

Drukis, P., Gaile, L., \& Goremikins, V. (2017). Case study of structural reliability of existing building. In $11^{\text {th }}$ International Scientific and Practical Conference ,Environment. Technology. Resources”. Rezekne, Latvia. https://doi.org/10.17770/etr2017vol3.2615

Drukis, P., Gaile, L., \& Pakrastins, L. (2017). Inspection of public buildings based on risk assessment. Procedia Engineering, 172, 247-255. https://doi.org/10.1016/j.proeng.2017.02.106

Drukis, P., Gaile, L., Valtere, K., Pakrastins, L., \& Goremikins, V. (2017). Study of structural reliability of existing concrete structures. In $3^{\text {rd }}$ International Conference ,Innovative Materials, Structures and Technologies”. Riga, Latvia. https://doi.org/10.1088/1757-899X/251/1/012087

EU Regulation for construction products. (2011). EU Regulation No 305/2011 of the European Parliament and of the Council of 9 March 2011 laying down harmonised conditions for the marketing of construction products and repealing Council Directive 89/106/EEC. Strasbourg. Retrieved from https://eur-lex.europa.eu/legal-content/EN/TXT/?uri=CELEX:32011R0305

FIB 80. (2016). Partial factor methods for existing concrete structures. Recommendations. The International Federation for Structural Concrete (fib) Bulletin. No. 80, 129 p.

Holicky, M., Diamantidis, D., \& Sykora, M. (2015). Determination of target safety for structures. In $12^{\text {th }}$ International Conference on Applications of Statistics and Probability in Civil Engineering, ICASP12, 12-15 July 2015. Vancouver, Canada.

Implementation of Eurocodes. Handbook 2. (2005) Reliability background. Guide to basis of structural reliability and risk engineering related to Eurocodes, supplemented by practical examples. Leonardo da Vinci pilot project CZ/02/B/F/PP134007. Prague 10. Retrieved from http://www.eurocodes.fi/1990/paasivu1990/sahkoinen1990/handbook2\%5B1\%5D.pdf

Latvian Parliament. (2013). Construction Law. Retrieved from https://ikumi.lv/ta/en/en/id/258572-construction-law

Luechinger, P., \& Fischer, J. (2015). New European Technical Rules for the assessment and retrofitting of existing structures. European Commission, Joint Research Centre, Institute for the Protection and Security of the Citizen. Retrieved from https://ec.europa.eu/jrc/en/publication/eur-scientific-and-technical-research-reports/new-european-technical-rulesassessment-and-retrofitting-existing-structures

Nico, Dr., Scholten, P. M., \& Vrouwenvelder, C. W. M. (2013). Eurocodes and structural safety of the existing buildings considering the publication of the Dutch NEN 8700. In $4^{\text {th }}$ International Conference Civil Engineering 13, Proceeding Part II, Building and Renovation.

OpenExp Report. (2016). Energy Transition of the EU Building Stock. Retrieved from https://www.openexp.eu/sites/default/files/publication/files/Reports/energy_transition_of_the_eu_building_stock_full_repor t.pdf

Perel'muter, A. V., \& Pichugin, S. F. (2014). Ob otsenke uyazvimosti stroitel'nykh konstruktsiy. Magazine of Civil Engineering, 5, 5-14 (in Russian). https://doi.org/10.5862/MCE.49.1

Puyenbroeck, T., \& Rogge, N. (2016). Geometric mean quantity index numbers with Benefit-of-the-Doubt weights. European Journal of Operational Research, 256(3), 1004-1014. https://doi.org/10.1016/j.ejor.2016.07.038

Sykora, M., Holicky, M., Jung, M., \& Diamantidis, D. (2015). Target reliability levels for assessment of existing structures considering economic and societal aspects. Life-Cycle of Structural Systems - Furuta, Frangopol \& Akiyama (Eds.). Taylor \& Francis Group, London. 